\title{
ANALISIS CO BENEFIT DI SENTRA INDUSTRI TAHU ADIWERNA, KABUPATEN TEGAL
}

\author{
Taty Hernaningsih \\ Peneliti di Pusat Teknologi Lingkungan \\ Badan Pengkajian dan Penerapan Teknologi
}

\begin{abstract}
"Co-benefits" refers to multiple benefits in different fields resulting from one policy, strategy or action plan. As an example: policy or strategy taken on reducing GHG emission from transportation, would ensure better air quality, health, promoting the use of biofuels and other alternative energy sources. I ndustrial waste water or domestic wastewater household if not disposed of or treated with either will cause pollution. The high content of organic content in wastewater will lead to GHG emissions impact on society as well as water pollution and odor pollution, Environmental Management in Industry Centers Adiwerna Tofu, Tegal regency was done by the management (cleaner production) and waste water treatment. Co Benefit analysis showed the relationship of environmental quality improvement occurs with the reduction of COD and capture methane gas that can be utilized for the community. The reduction of emissions in air can reduce GHG. Method of estimated GHG reduction can be done by comparing GHG emissions before the project (baseline - BE) and after the implementation of projects cobenefits (project - PE). The evaluation was done by grouping into 3 tiers. Evaluation indicators are $C O D, B O D 5$, smell, $\mathrm{CH}_{4}$, while other indicators are $\mathrm{N}, \mathrm{P}$ and hazardous waste indicators concerning health. To get the best results of the evaluation required complete data.
\end{abstract}

Keywords : GRK, Co-benefit,Tier, Metana, COD

\section{PENDAHULUAN}

\subsection{Latar Belakang}

Pengertian "Co-benefits" merupakan keuntungan berganda di beberapa hal yang diperoleh dari satu kebijakan, strategi atau rencana kegiatan ${ }^{(1)}$. Sebagai contoh, strategi yang digunakan untuk mengatasi perubahan iklim juga dapat memberikan akibat yang positip di bidang lainnya, seperti perbaikan lingkungan hidup serta perbaikan ekonomi masyarakat, dimana misalnya, kebijakan atau strategi yang dilakukan dalam pengurangan emisi Gas Rumah Kaca (GRK) dari sektor transportasi, akan meningkatkan kualitas udara dan kualitas kesehatan, yaitu dengan cara meningkatkan penggunaan biofuel dan sumber energi alternatif lainnya.

Menurut Kementerian Lingkungan Hidup Jepang (Japan's Ministry of Environment $(M E O J))$ pendekatan co-benefits dalam penanganan perubahan iklim dan CDM mencakup inisiatif untuk memenuhi kebutuhan bagi negara berkembang di satu sisi dan juga sekaligus mitigasi perubahan iklim, di sisi lain. Pelaksanaan CDM sangat penting untuk dapat mengatasi permasalahan pembangunan sosial ekonomi dan lingkungan yang menjadi isu pokok di negara berkembang seperti Indonesia (2). Secara umum, gambaran konsep co-benefit dapat dilihat pada gambar 1 .

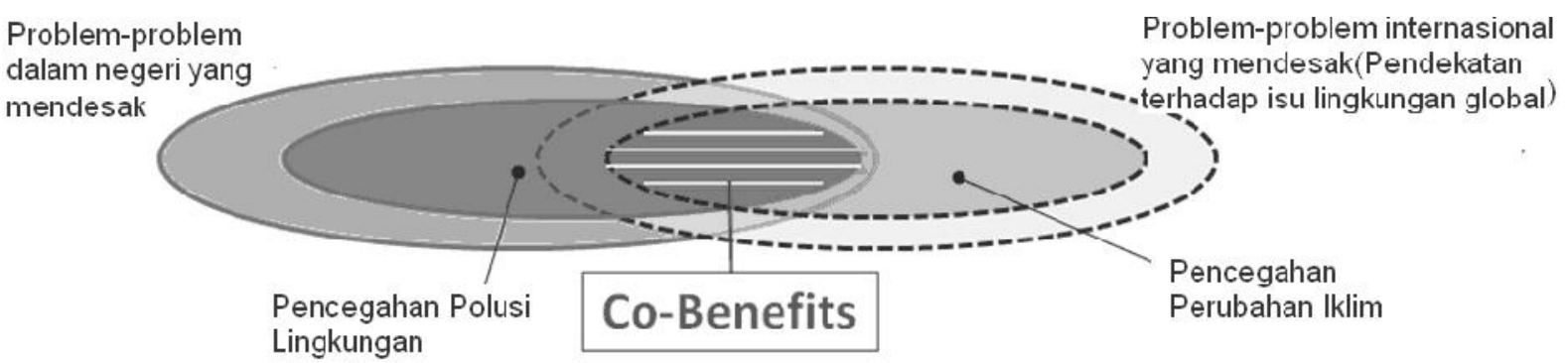

Gambar 1. Konsep Co-Benefits (5)

Gambar 1 diatas menunjukkan bahwa terdapat permasalahan dalam negeri yang mendesak untuk segera diselesaikan dan disisi lain terdapat pula permasalahan yang bersifat 
internasional seperti permasalahan perubahan iklim yang juga segera harus diselesaikan dengan cepat. Dua permasalahan ini diselesaikan secara bersamaan dengan melakukan penanganan pencemaran lingkungan untuk dalam negeri dan penanganan permasalahan internasional seperti perubahan iklim. Dalam gambar diatas ada bagian dimana dapat dilakukan pendekatan co-benefit. Pendekatan ini merupakan sinergi yang erat antara mitigasi perubahan iklim dan kegiatan pembangunan berkelanjutan, seperti juga yang telah dilakukan oleh negera berkembang ${ }^{(6)}$.

Sebagai bagian dari rencana pemerintah dalam mitigasi perubahan iklim, pemerintah Indonesia telah mengembangkan roadmap terjadinya perubahan iklim termasuk kegiatankegiatan yang berkaitan di beberapa sektor pembangunan. Sesuai dengan tugas dan fungsinya, maka Kementerian Lingkungan Hidup telah ikut serta dalam mempersiapkan roadmap di sektor pengendalian pencemaran.

Kementerian Lingkungan Hidup telah melakukan kegiatan co-benefit melalui kegiatan seminar serta studi kelayakan. Kegiatan-kegiatan ini perlu disebarkan kepada pemerintahan daerah sehingga pemerintah daerah dapat mengintegrasikan kegiatan pengurangan emisi GRK ke dalam kegiatan-kegiatan pengelolaan lingkungan hidup masyarakat.

Salah satu kegiatan percontohan dalam pengendalian pencemaran yang dilakukan Kementerian Lingkungan Hidup adalah industri kecil adalah Sentra Industri Tahu Adiwerna, Kabupaten Tegal. Industri tahu atau limbah cair domestik rumah tangga jika dibuang atau diolah dengan tidak baik akan menyebabkan pencemaran. Tingginya kandungan kandungan organik dalam air limbah akan menyebabkan emisi metana yang berdampak negatif kepada masyarakat seperti halnya dengan pencemaran air dan pencemaran bau,

Teknologi pengolahan dan peralatan yang lebih baik dan tepat akan menghasilkan co benefit dan pemecahan masalah tersebut. Pendekatan co-benefit dalam pencegahan pencemaran lingkungan dan perubahan iklim perlu dilaksanakan, karena memiliki banyak keuntungan. Keuntungan dalam lingkungan/ pembangunan berkelanjutan, diantaranya: pengurangan dampak pencemaran udara dan air, lingkungan serta udara yang lebih bersih, mengurangi bau dalam pengelolaan limbah, meningkatkan sanitasi lingkungan yang lebih baik, pengurangan emisi GRK dan pengurangan risiko kebakaran. Sedangkan keuntungan ekonomi/pembangunan adalah penambahan penghasilan melalui penggunaan gas metana, pengurangan biaya operasi dari substitusi energi yang berasal dari metana. Kegiatan yang akan dievaluasi co benefit adalah pengolahan air limbah di Sentra Industri Tahu Tahu Adiwerna, Kabupaten Tegal.

\subsection{Tujuan dan Sasaran}

Tujuan kegiatan adalah melakukan evaluasi Co Benefit terhadap pengolahan air limbah di Sentra Industri Tahu Tahu Adiwerna, Kabupaten Tegal. Adapun sasarannya adalah agar masyarakat mengetahui bahwa dengan pengelolaan lingkungan yang baik akan memberikan keuntungan yang ganda baik untuk lingkungan, kesehatan maupun untuk ekonominya, Dengan pengelolaan lingkungan di industri kecil ini diharapkan dapat merupakan contoh bagi industri kecil lainnya, industri besar ataupun kegiatan lain yang menghasilkan air limbah untuk turut serta melaksanakan pengelolaan lingkungan.

\section{METODOLOGI}

Estimasi penurunan GRK dapat dilakukan dengan membandingkan emisi GRK awal (baseline - BE) serta GRK setelah implementasi proyek co-benefits (project - PE). Metodologi pengurangan GRK dengan persamaan ${ }^{(3),(5)}$ :

$\mathrm{ER}_{\mathrm{CO}_{2}, \mathrm{y}}=\mathrm{BE}_{\mathrm{CO}_{2}, \mathrm{y}}-\mathrm{PE}_{\mathrm{CO}_{2}, \mathrm{y}}$

Dimana :

$\mathrm{ER} \mathrm{co}_{2, \mathrm{y}}=\mathrm{BE} \mathrm{CO}, \mathrm{y}-\mathrm{PE} \mathrm{co}, \mathrm{y}$

ERco2,y: Pengurangan emisi GRK (tCo2e)

$\mathrm{BE}_{\mathrm{CO} 2, \mathrm{y}}$ : Emisi GRK skenario awal ( $\mathrm{tCo}_{\mathrm{O} e}$ )

$\mathrm{BE}_{\mathrm{CO} 2, \mathrm{y}}$ : Emisi GRK Skenario setelah projek

(tCo2e)

Metodologi untuk evaluasi level COD yang terdapat dalam air limbah setelah adanya projek dapat dihitung dengan persamaan:

ER COD = BE COD - PE COD

Dimana,

ER

BE $\mathrm{COD}$ : COD Skenario awal (ton/tahun)

BE $C O D$ : COD Skenario setelah projek (ton/tahun)

Secara umum metode perhitungan didasarkan pada Draft Manual for Quantitative Evaluation of the Co-Benefitss Approach to Climate Change (5). Namun demikian, ada beberapa pendekatan dibuat berdasarkan data dari IPCC serta US-EPA, yang dirasa lebih sederhana serta lebih mudah diaplikasikan oleh pemerintah daerah.

Berdasarkan Draft Manual di atas, tingkatan metodologi evaluasi yang digunakan dapat dikelompokkan ke dalam 3 tingkatan Tier (Tingkat Kesulitan), seperti terlihat pada Tabel 1. 
Tabel 1. Metodologi Evalusi Untuk Kegiatan Co-Benefits

\begin{tabular}{|c|c|c|}
\hline Tingkatan & $\begin{array}{l}\text { Metodologi } \\
\text { Evaluasi }\end{array}$ & Keterangan \\
\hline Tier 1 & $\begin{array}{l}\text { Tidak dilakukan } \\
\text { perhitungan, } \\
\text { evaluasi } \\
\text { dilakukan } \\
\text { berdasarkan } \\
\text { kriteria evaluasi } \\
\text { yang dibuat } \\
\text { secara khusus } \\
\text { untuk kegiatan } \\
\text { tersebut }\end{array}$ & $\begin{array}{l}\text { Pembuatan persamaan } \\
\text { perhitungan } \\
\text { keuntungan kegiatan } \\
\text { co-benefits sulit } \\
\text { dilakukan, serta data } \\
\text { sangat sulit didapat. } \\
\text { Keuntungan dapat } \\
\text { dievaluasi berdasarkan } \\
\text { kriteria-kriteria kualitatif } \\
\text { yang telah ditentukan } \\
\text { sebelumnya }\end{array}$ \\
\hline Tier 2 & $\begin{array}{l}\text { Evaluasi secara } \\
\text { kuantitatif } \\
\text { dilakukan } \\
\text { seperlunya, } \\
\text { menggunakan } \\
\text { persamaan serta } \\
\text { data pengukuran } \\
\text { yang ada }\end{array}$ & $\begin{array}{l}\text { Tingkatan ini } \\
\text { menggunakan data } \\
\text { pengukuran aktual } \\
\text { untuk mengevaluasi } \\
\text { kegitan co-benefit. } \\
\text { Kalau data pengukuran } \\
\text { tidak ada, maka } \\
\text { evaluasi dilakukan } \\
\text { menggunakan data- } \\
\text { data dasar (default) }\end{array}$ \\
\hline Tier 3 & $\begin{array}{l}\text { Evaluasi } \\
\text { kuantitatif } \\
\text { dilakukan } \\
\text { menggunakan } \\
\text { data pengukuran } \\
\text { untuk aktivitas } \\
\text { tersebut, juga } \\
\text { menggunaan } \\
\text { persamaan- } \\
\text { persamaan } \\
\text { spesifik }\end{array}$ & $\begin{array}{l}\text { Tingkatan ini } \\
\text { menggunakan data- } \\
\text { data pengukuran aktual } \\
\text { serta persamaan- } \\
\text { persamaan yang } \\
\text { bersifat spesifik }\end{array}$ \\
\hline
\end{tabular}

Berdasarkan Tabel 1 dalam melakukan evaluasi, maka kegiatan evaluasi dapat digolongkan menjadi tiga tingkatan seperti Tabel 2.

Tabel 2. Tingkatan Indikator Evaluasi Berdasarkan Tingkat Kesulitannya

\begin{tabular}{|l|l|l|}
\hline Tingkatan & \multicolumn{1}{|c|}{ Tingkatan evaluasi } & \multicolumn{1}{|c|}{$\begin{array}{c}\text { Contoh } \\
\text { Indikator }\end{array}$} \\
\hline Tier 1 & $\begin{array}{l}\text { Evaluasi sulit } \\
\text { dilakukan secara } \\
\text { kuantitatif, serta hanya } \\
\text { dapat dilakukan } \\
\text { secara kualitatif }\end{array}$ & $\begin{array}{l}\text { Stimulasi } \\
\text { ekonomi dan } \\
\text { lain-lain. }\end{array}$ \\
\hline Tier 2 & $\begin{array}{l}\text { Pengambilan data } \\
\text { dilapangan serta } \\
\text { evaluasi kuantitatif } \\
\text { menggunakan }\end{array}$ & $\begin{array}{l}\text { COD, SOx, } \\
\text { konsumsi BBM, } \\
\mathrm{CH}_{4} \text { dan lain- } \\
\text { lain. }\end{array}$ \\
\hline
\end{tabular}

\begin{tabular}{|c|c|c|}
\hline & $\begin{array}{l}\text { persamaan- } \\
\text { persamaan standar } \\
\text { mudah dilakukan }\end{array}$ & \\
\hline Tier 3 & $\begin{array}{l}\text { Pengambilan data } \\
\text { dilapangan serta } \\
\text { evaluasi kuantitatif } \\
\text { menggunakan } \\
\text { persamaan- } \\
\text { persamaan spesifik } \\
\text { lebih sulit dilakukan }\end{array}$ & $\begin{array}{l}\text { Penurunan } \\
\text { jumlah debit air, } \\
\text { nilai ekonomis } \\
\text { perbaikan } \\
\text { kualitas } \\
\text { lingkungan, dan } \\
\text { lain-lain. }\end{array}$ \\
\hline
\end{tabular}

Dalam metodologi ini ditentukan indikator utama yang perlu dievaluasi untuk pendekatan co-benefits dalam kategori peningkatan kualitas air tabel 3. Kategori ini memfokuskan pada limbah cair yang berasal dari kegiatan rumah tangga dan industri. Meskipun tidak berhubungan langsung ngan GRK, indikator-indikator lain juga perlu dievaluasi, seperti Nitrogen $(N)$, Fosfor $(P)$ dan B3 yang dapat mengganggu kesehatan manusia (Tabel 4).

\section{SUMBER KATAGORI DAN POTENSI EMISI GRK}

Air limbah merupakan sumber metana jika diolah secara anaerobik atau dibiarkan tidak dilakukan pengolahan. Selain itu air limbah juga merupakan sumber emisi $\mathrm{N}_{2} \mathrm{O}$. Dalam hal ini emisi $\mathrm{CO}_{2}$ dari air limbah tidak dimasukkan dalam perhitungan sebagai sumber-sumber organik. Sumber katagori dalam air limbah dapat dilihat pada Tabel 5. Untuk menentukan co benefit harus diperhatikan karakteristik diagram alir air dalam suatu sistem pengelolaan air limbah.

\section{KEGIATAN CO-BENEFITS YANG BERPOTENSI}

Dalam pegelolaan air limbah terdapat beberapa sektor potensial yang dapat dibahas kegiatan co-benefit-nya. Berdasarkan penyelenggaranya, maka kegiatan co-benefit dapat dikatagorikan dalam sektor-sektor di bawah ini:

- Kegiatan pengelolaan lingkungan yang dilakukan oleh pemerintah pusat/daerah.

- Kegiatan pengelolaan lingkungan yang dilakukan berdasarkan inisiatif dari masyarakat.

- Kegiatan pengelolaan lingkungan yang dilakukan oleh pihak swasta.

Berdasarkan lingkup aktivitasnya, maka kegiatan co-benefit peningkatan kualitas air dan teknologi yang digunakan dapat disajikan dalam seperti Tabel 6 di bawah ini. 
Tabel 3. Indikator Evaluasi Untuk Kategori Peningkatan Kualitas Air

\begin{tabular}{|l|l|l|l|}
\hline \multicolumn{1}{|c|}{$\begin{array}{c}\text { Indikator } \\
\text { Evaluasi }\end{array}$} & \multicolumn{1}{|c|}{ Keterangan } & \multicolumn{1}{c|}{ Kegunaan Indikator } & \multicolumn{1}{c|}{ Target } \\
\hline $\begin{array}{l}\text { Chemical } \\
\text { Oxygen Demand } \\
(C O D)\end{array}$ & $\begin{array}{l}\text { Limbah organik yang } \\
\text { terkandung dalam air limbah } \\
\text { domestik dan industri }\end{array}$ & $\begin{array}{l}\text { Evaluasi penurunan polusi } \\
\text { berdasarkanpenurunan } \\
\text { konsentrasi COD dalam limbah } \\
\text { cair, yang diakibatkan adanya } \\
\text { proyek }\end{array}$ & $\begin{array}{l}\text { Pencegahan } \\
\text { Polusi } \\
\text { Lingkungan }\end{array}$ \\
\hline $\begin{array}{l}\text { Biological } \\
\text { Oxygen Demand } \\
\left(B O D_{5}\right)\end{array}$ & $\begin{array}{l}\text { Limbah organik yang } \\
\text { terkandung dalam air limbah } \\
\text { domestik dan industri }\end{array}$ & $\begin{array}{l}\text { Evaluasi penurunan polusi } \\
\text { berdasarkanpenurunan } \\
\text { konsentrasi BOD dalam limbah } \\
\text { cair, yang diakibatkan adanya } \\
\text { proyek }\end{array}$ & $\begin{array}{l}\text { Pencegahan } \\
\text { Polusi } \\
\text { Lingkungan }\end{array}$ \\
\hline Bau & $\begin{array}{l}\text { Bau yang tidak sedap dari } \\
\text { adanya degradasi bahan } \\
\text { organik dalam limbah }\left(\mathrm{H}_{2} \mathrm{~S}\right. \\
\text { and volatile organic carbon) }\end{array}$ & $\begin{array}{l}\text { Evaluasi penurunan derajat bau } \\
\text { yang diakibatkan adanya proyek }\end{array}$ & $\begin{array}{l}\text { Pencegahan } \\
\text { Polusi } \\
\text { Lingkungan }\end{array}$ \\
\hline Metana $\left(\mathrm{CH}_{4}\right)$ & $\begin{array}{l}\text { GRK yang dihasilkan dari } \\
\text { degradasi bahan organik } \\
\text { secara anaerobik }\end{array}$ & $\begin{array}{l}\text { Evaluasi penurunan emisi GRK } \\
\text { berdasarkan penurunan emisi } \\
\text { metana yang diakibatkan adanya } \\
\text { proyek }\end{array}$ & $\begin{array}{l}\text { Pencegahan } \\
\text { perubahan } \\
\text { iklim }\end{array}$ \\
\hline $\begin{array}{l}\text { Karbon dioksida } \\
\left(\mathrm{CO}_{2}\right)\end{array}$ & $\begin{array}{l}\text { GRK yang dihasilkan dari } \\
\text { pembakaran BBM untuk } \\
\text { listrik, atau untuk } \\
\text { pengoperasian IPAL }\end{array}$ & $\begin{array}{l}\text { Evaluasi penurunan emisi karbon } \\
\text { dioksida akibat penurunan } \\
\text { penggunaan BBM yang } \\
\text { diakibatkan adanya proyek }\end{array}$ & $\begin{array}{l}\text { Pencegahan } \\
\text { perubahan } \\
\text { iklim }\end{array}$ \\
\hline
\end{tabular}

Tabel 4. Indikator Evaluasi Untuk Kategori Perbaikan Kualitas Air Untuk N, P Dan B3

\begin{tabular}{|l|l|l|l|}
\hline \multicolumn{1}{|c|}{ Indikator } & \multicolumn{1}{|c|}{ Keterangan } & \multicolumn{1}{|c|}{ Kegunaan Indikator } & \multicolumn{1}{|c|}{ Target } \\
\hline Nitrogen (N) & $\begin{array}{l}\text { Senyawa yang } \\
\text { mengakibatkan adanya } \\
\text { eutrofikasi }\end{array}$ & $\begin{array}{l}\text { Evaluasi penurunan pencemaran dari } \\
\text { penurunan konsentrasi N yang } \\
\text { diakibatkan adanya proyek }\end{array}$ & $\begin{array}{l}\text { Pencegahan } \\
\text { polusi } \\
\text { lingkungan }\end{array}$ \\
\cline { 1 - 3 } Fosfor $(\mathrm{P})$ & $\begin{array}{l}\text { Senyawa yang } \\
\text { mengakibatkan adanya } \\
\text { eutrofikasi }\end{array}$ & $\begin{array}{l}\text { Evaluasi penurunan pencemaran dari } \\
\text { penurunan konsentrasi P yang } \\
\text { diakibatkan adanya proyek }\end{array}$ & \\
\cline { 1 - 2 } & $\begin{array}{l}\text { Senyawa yang dapat } \\
\text { mengganggu kesehatan } \\
\text { manusia }\end{array}$ & $\begin{array}{l}\text { Evaluasi penurunan pencemaran dari } \\
\text { penurunan konsentrasi B3 yang } \\
\text { diakibatkan adanya proyek }\end{array}$ & \\
\hline
\end{tabular}

Tabel 5. Sumber Katagori dan Emisi GRK (6)

\begin{tabular}{|c|c|c|c|c|c|}
\hline \multicolumn{4}{|c|}{ Tipe Pengolahan dan Pembuangan } & Potensi Emisi $\mathrm{CH}_{4}$ dan $\mathrm{N}_{2} \mathrm{O}$ & Keterangan \\
\hline \multirow{5}{*}{ 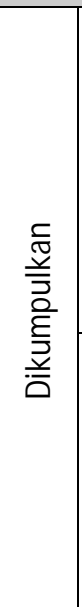 } & \multirow{3}{*}{ 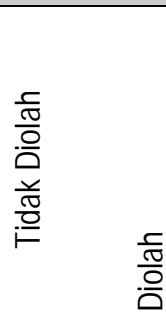 } & & Dibuang ke sungai & & $\begin{array}{l}\text { Sungai dengan beban organik tinggi } \\
\text { dapat berubah menjadi anaerobik }\end{array}$ \\
\hline & & & $\begin{array}{l}\text { Saluran(tertutup } \\
\text { dan di bawah } \\
\text { tanah) }\end{array}$ & Bukan sumber $\mathrm{CH}_{4}$ dan $\mathrm{N}_{2} \mathrm{O}$ & $\begin{array}{l}\text { Pergerakan cepat, bersih(tidak } \\
\text { signifikan jumlah } \mathrm{CH} 4 \text { dari stasiun } \\
\text { pompa) }\end{array}$ \\
\hline & & & Saluran (terbuka) & $\begin{array}{l}\text { Tidak mengalir, saluran/kanal } \\
\text { sudah penuh kemungkinan jelas } \\
\text { sebagai sumber } \mathrm{CH}_{4}\end{array}$ & Terbuka dan hangat \\
\hline & \multirow{2}{*}{$\frac{\frac{0}{\pi}}{\frac{\pi}{0}}$} & \multirow{2}{*}{$\frac{\text { 产 }}{\frac{0}{2}}$} & \multirow{2}{*}{$\begin{array}{l}\text { Pengolahan } \\
\text { anaerobik dengan } \\
\text { lumpur aktif di } \\
\text { instalasi } \\
\text { pengolahan air } \\
\text { limbah secara } \\
\text { aerobik dengan }\end{array}$} & \multirow{2}{*}{$\begin{array}{l}\text { Kemungkinan menghasilkan } \\
\mathrm{CH}_{4} \text { terbatas dari sumber } \\
\text { anaerobik.. } \\
\text { Instalasi pengolahan lanjutan } \\
\text { dengan penghilangan nutrient } \\
\text { (nitrifikasi dan denitrifikasi) } \\
\text { sedikit tetapi tidak terlihat }\end{array}$} & $\begin{array}{l}\text { Harus dikelola dengan baik. atau } \\
\text { sumber-sumber lain. Sebagian } \mathrm{CH} 4 \\
\text { dapat diemisi dari bak pengendap }\end{array}$ \\
\hline & & & & & $\begin{array}{l}\text { Pengelolaan tidak baik. Terlalu } \\
\text { penuh }\end{array}$ \\
\hline
\end{tabular}




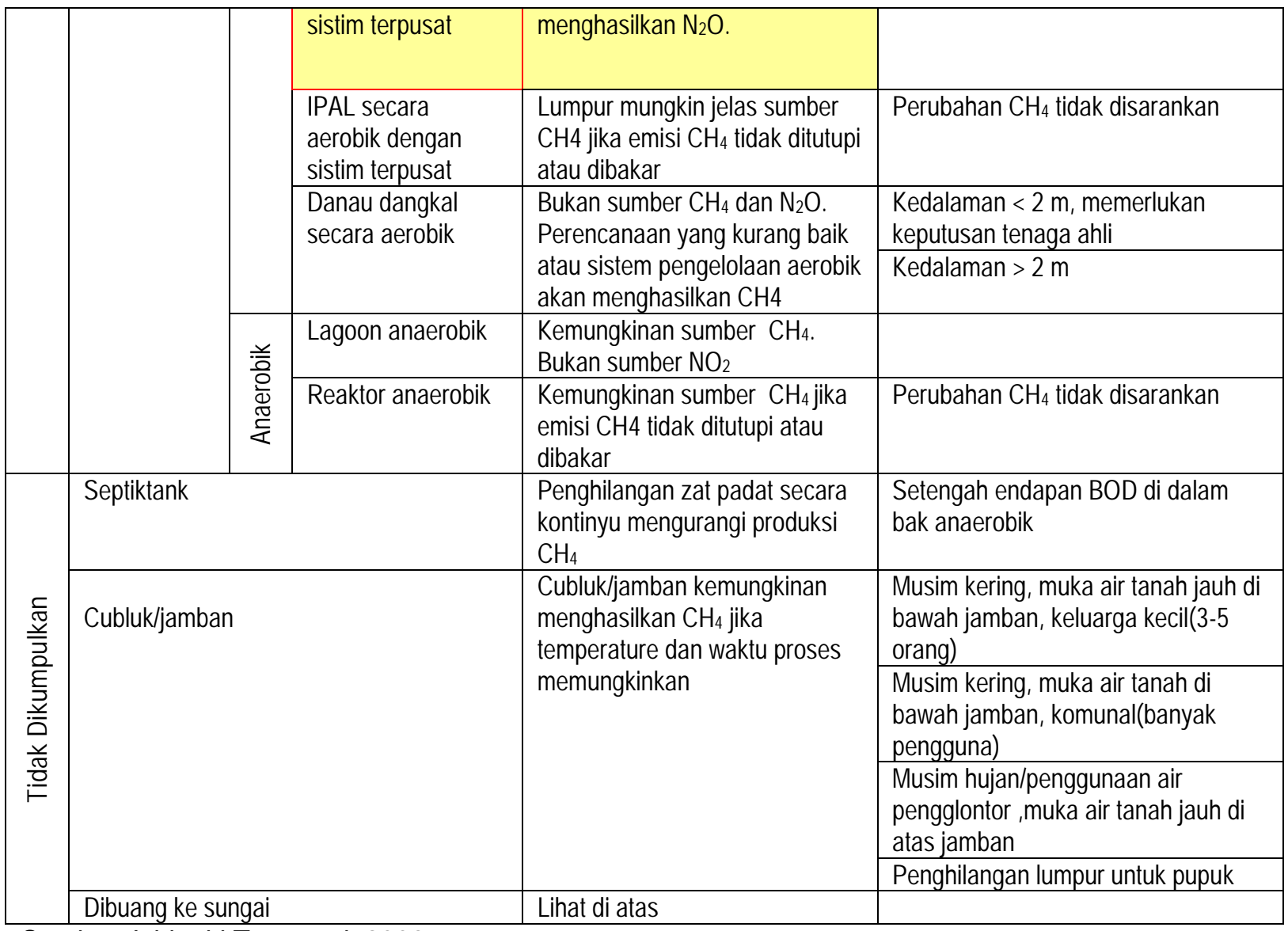

Sumber: Ishigaki Tomonori, 2009.

Tabel 6: Teknologi dalam Kegiatan Co-benefit di Indonesia untuk Peningkatan Kualitas Air

\begin{tabular}{|c|c|c|c|c|}
\hline No & $\begin{array}{l}\text { Jenis } \\
\text { Teknologi }\end{array}$ & $\begin{array}{l}\text { Aktivitas menggunakan } \\
\text { pendekatan co-benefits }\end{array}$ & $\begin{array}{c}\text { Efek Penurunan } \\
\text { GRK }\end{array}$ & Co-Benefit \\
\hline 1 & $\begin{array}{l}\text { Teknologi } \\
\text { Biofilter } \\
\text { Kombinasi } \\
\text { Anaerobik- } \\
\text { Aerobik }\end{array}$ & $\begin{array}{l}\text { Pengolahan limbah organic } \\
\text { konsentrasi tinggi secara } \\
\text { anaerobik, seperti Semanan, } \\
\text { Jakarta Barat, atau Sentra } \\
\text { Industri Tahu di Tegal, Limbah } \\
\text { Peternakan babi Pulau Bulan, } \\
\text { MCK komunal di Petojo, Jakarta. }\end{array}$ & $\begin{array}{l}\text { Menurunkan } \\
\text { emisi gas metana } \\
\text { ke atmosfir } \\
\text { dengan } \\
\text { melakukan } \\
\text { pekeuntunganan } \\
\text { gas yang muncul. }\end{array}$ & $\begin{array}{l}\text { Mengurangi jumlah pencemar } \\
\text { yang masuk ke lingkungan, } \\
\text { Meningkatkan kesehatan } \\
\text { lingkungan, Mengurangi } \\
\text { pencemaran air tanah dangkal, } \\
\text { Mengurangi bau akibat limbah. }\end{array}$ \\
\hline 2 & $\begin{array}{l}\text { Teknologi } \\
\text { Kolam } \\
\text { Oxidation } \\
\text { Ditch (Sistem } \\
\text { Aerobik) }\end{array}$ & $\begin{array}{l}\text { Pengolahan limbah industri skala } \\
\text { besar untuk menurunkan } \\
\text { konsentrasi limbah pencemaran, } \\
\text { seperti di Kawasan Industry } \\
\text { Jababeka. }\end{array}$ & $\begin{array}{l}\text { Menurunkan } \\
\text { Emisi } \mathrm{N}_{2} \mathrm{O} \text { ke } \\
\text { udara. }\end{array}$ & $\begin{array}{l}\text { Mengurangi jumlah pencemar } \\
\text { yang masuk ke lingkungan, } \\
\text { Meningkatkan kesehatan } \\
\text { lingkungan, Mengurangi } \\
\text { pencemaran air tanah dangkal, } \\
\text { Mengurangi bau akibat limbah. }\end{array}$ \\
\hline 3 & $\begin{array}{l}\text { Teknologi } \\
\text { Reaktor } \\
\text { Anaerobik }\end{array}$ & $\begin{array}{l}\text { Pengolahan Limbah dari Rumah } \\
\text { Pemotongan Hewan (RPH) di } \\
\text { Cakung, Jakarta dan } \\
\text { Suwung-Denpasar) }\end{array}$ & $\begin{array}{l}\text { Menurunkan } \\
\text { emisi gas } \\
\text { metanaa, jika } \\
\text { dilakukan } \\
\text { pembakaran gas } \\
\text { (flaring). }\end{array}$ & $\begin{array}{l}\text { Mengurangi pencemaran yang } \\
\text { masuk ke lingkungan sekitar, } \\
\text { mengurangi pencemaran air } \\
\text { tanah dan Mengurangi bau } \\
\text { serta gejolak sosial. }\end{array}$ \\
\hline 4 & $\begin{array}{l}\text { Teknologi } \\
\text { Pengelolaan } \\
\text { Limbah } \\
\text { Leachate }\end{array}$ & $\begin{array}{l}\text { Menetralkan kemasaman air, } \\
\text { menurunkan kandungan organic } \\
\text { dalam air limbah }\end{array}$ & $\begin{array}{l}\text { Penurunan emisi } \\
\mathrm{CH}_{4}\end{array}$ & $\begin{array}{l}\text { Mencegah timbulnya bau tidak } \\
\text { sedap, Meningkatkan pH air, } \\
\text { Mengurangi pencemaran } \\
\text { bahan organic, Meningkatkan } \\
\text { kesehatan lingkungan }\end{array}$ \\
\hline
\end{tabular}




\section{EVALUASI CO BENEFT DALAM PENINGKATAN KUALITAS AIR}

Evaluasi proyek co-benefits akan sangat tergantung pada kondisi lokal yang berbeda-beda untuk tiap daerah, tergantung target, serta harus dapat diaplikasikan secara mudah dan efektif. MOEJ (2009) menyatakan bahwa evaluasi hendaknya didasarkan pada kriteria-kriteria di bawah (1):

- Dapat merefleksikan inisiatif dari pemerintah daerah, mempertimbangkan keragaman masalah di tiap daerah serta pendekatan yang mungkin berbeda dalam mengimplementasikan pembangunan berkelanjutannya.

- Transparan, adil, serta dapat direproduksi di tempat lain.

- Dapat diimplementasikan secara cepat dan mudah.

Salah satu kegiatan co-benefits yang telah dilaksanakan adalah di Sentra Industri Tahu di Desa Adiwerna, Kabupaten Tegal - Jawa Tengah. Di Desa Adiwerna Kecamatan Adiwerna terdapat $464 \mathrm{KK}, 400$ pengrajin tahu. Di Dukuh Pesalakan terdapat 278 pengrajin tahu dan mempunyai dua unit IPAL namun kapasitas IPAL terpasang tidak sesuai dengan air limbah yang diolah, satu IPAL melayani 150 pengrajin dan satu lagi melayani 138 pengrajin. Debit air limbah yang diolah $\mathrm{IPAL}$ sebesar $225 \mathrm{~m}^{3} /$ hari. Disamping Desa Adiwerna, sentra industri tahu juga terdapat dibeberapa desa lain, yaitu Desa Kemranggen, Pekiringan, dan Desa Harjosari Lor.

Dengan bantuan teknis dari KLH, Desa Adiwerna telah membuat unit pengolahan limbah yang terpusat, di daerah utara dan selatan, dengan kapasitas total $225 \mathrm{~m}^{3}$ limbah per hari, dengan sistem Dewats, yang juga digunakan di RPH Pesanggarahan, Denpasar (4). Anaerobic digester dan kompor yang menggunakan gas metana dapat dilihat pada Gambar 1 dan Gambar 2.

Kegiatan co-benefits yang lakukan meliputi dua bagian utama, yaitu perbaikan manajemen limbah, serta pengelolaan limbah cair secara terpusat. Kegiatan yang pertama meliputi perbaikan sistem pembuatan tahu dengan pendekatan industri bersih. Kegiatan ini memberikan kontribusi terhadap penurunan jumlah limbah cair yang dihasilkan, serta penurunan jumlah energi yang digunakan. Kegiatan selanjutnya adalah pembuatan fasilitas pengolahan limbah cair tahu dengan metode anaerobik yang dipadukan dengan sistem lagoon. Kegiatan ini, memiliki dampak positif terhadap:

a. Penurunan konsentrasi COD di effluen. b. Penangkapan gas metana, yang digunakan untuk sumber bahan bakar rumah tangga, saat ini sekitar 100 rumah tangga telah menggunakan sumber energi untuk kegiatan memasak dari biogas yang dihasilkan oleh dua fasilitas ini.

c. Penurunan indeks bau yang diakibatkan oleh terlepasnya volatile organik carbon dalam saluran limbah.

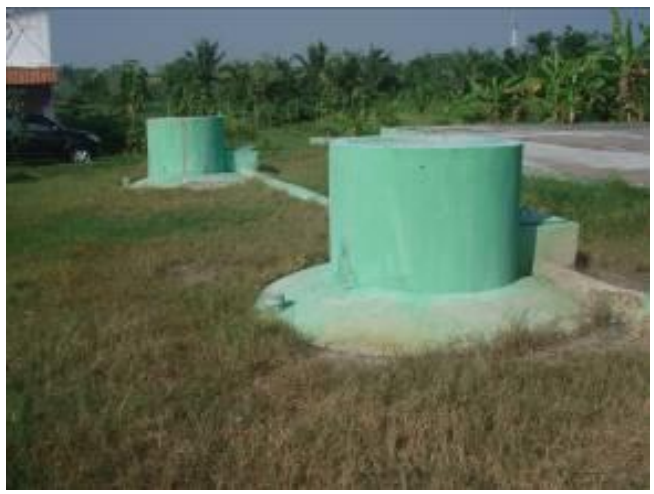

Gambar 1 Anaerobic Digester

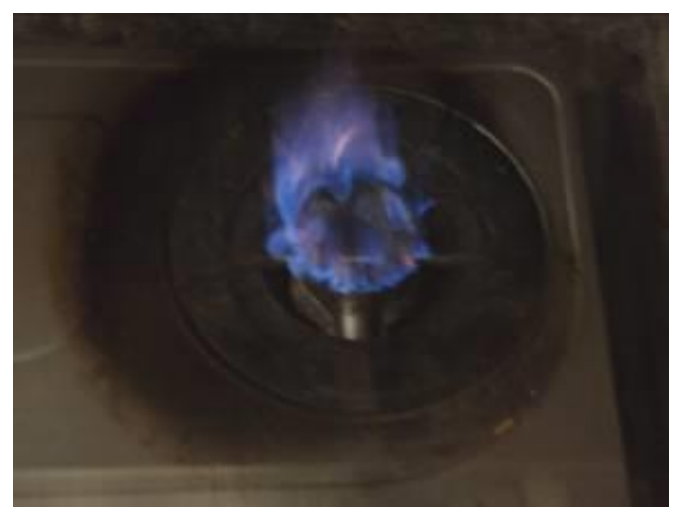

Gambar 2. Kompor Dengan Bahan Bakar Metana

Desain kedua unit pengolahan limbah ini adalah mampu mengolah sekitar $225 \mathrm{~m}^{3}$ limbah setiap hari, dengan hasil analisa kualitas air IPAL tanggal 20 Agustus 2010 sesuai tabel 7 .

Tabel 7. Hasil Analisis Kualitas Air Limbah Sebelum Serta Setelah Proses Pengolahan Di Sentra Industri Tahu Tegal

\begin{tabular}{|l|l|c|c|c|}
\hline No & Parameter & Utara & & Selatan \\
\hline & & I & II & III \\
\hline 1 & $\begin{array}{l}\text { IPAL UTARA } \\
\left(\mathrm{g} / \mathrm{m}^{3)}\right.\end{array}$ & 3080 & 81 & 65 \\
\hline 2 & $\begin{array}{l}\text { COD Tetal } \\
\left(\mathrm{g} / \mathrm{m}^{3)}\right.\end{array}$ & 1056 & 53 & 46 \\
\hline
\end{tabular}




\begin{tabular}{|l|l|c|c|c|}
\hline 3 & Nitrate $\left(\mathrm{g} / \mathrm{m}^{3)}\right.$ & 204.42 & 209.87 & 228.31 \\
\hline 4 & $\begin{array}{l}\text { Phosphate }(\mathrm{P}) \\
\left(\mathrm{g} / \mathrm{m}^{3)}\right.\end{array}$ & 9.88 & 10.79 & 9.15 \\
\hline 5 & $\mathrm{pH}$ & 6.56 & 8.39 & 8.37 \\
\hline & \multicolumn{2}{|l|}{ IPAL SELATAN } & & \\
\hline 6 & $\begin{array}{l}\text { COD Total } \\
\left(\mathrm{g} / \mathrm{m}^{3)}\right.\end{array}$ & 3168 & 76 & 70 \\
\hline 7 & $\begin{array}{l}\text { COD Terlarut } \\
\left(\mathrm{g} / \mathrm{m}^{3)}\right.\end{array}$ & 1188 & 41 & 42 \\
\hline 8 & Nitrate (g/m $\mathrm{m}^{3)}$ & 187.79 & 185.67 & 195.96 \\
\hline 9 & $\begin{array}{l}\text { Phosphate }(\mathrm{P}) \\
\left(\mathrm{g} / \mathrm{m}^{3)}\right.\end{array}$ & 10.08 & 10.35 & 9.85 \\
\hline 10 & $\mathrm{pH}$ & 5.45 & 8.34 & 8.36 \\
\hline
\end{tabular}

\section{a. Analisis Co-Benefits}

Analisis co-benefits pada kegiatan ini menggunakan Tier (Tingkat Kesulitan) 2 dan Tier (Tingkat Kesulitan) 3.

\section{b. Katagori Pengelolaan Limbah}

Dengan pengelolaan industri bersih, maka dapat diperoleh beberapa keuntungan yang dirasakan langsung oleh masyarakat. Salah satunya adalah penurunan volume limbah serta penurunan konsumsi bahan bakar yang digunakan. Seperti disampaikan pada tabel 8 berikut. Namun demikian, pada saat ini penurunan jumlah emisi, serta penurunan konsentrasi COD yang dihasilkan dari adanya proyek ini tidak dapat dikuantifikasi, karena ketiadaan data dasar.

Tabel 8. Peningkatan Efisiensi Pengolahan Tahu Sebagai Akibat Diterapkannya Produksi Bersih (Skenario Proyek)

\begin{tabular}{|c|l|c|}
\hline No & \multicolumn{1}{|c|}{ Komponen } & $\begin{array}{c}\text { Pencapaian } \\
\text { Effisiensi (\%) }\end{array}$ \\
\hline 1 & $\begin{array}{l}\text { Kebutuhan } \\
\text { kedelai/hari }\end{array}$ & - \\
\hline 2 & Luas lahan & 18,32 \\
\hline 3 & Penggunaan air & 50,24 \\
\hline 4 & Tenaga kerja & 42,71 \\
\hline 5 & Bahan bakar & 34 \\
\hline 6 & Waktu produksi & 49 \\
\hline 7 & Kuantitas tahu & 13,04 \\
\hline
\end{tabular}

\section{c. Katagori Peningkatan Kualitas Air}

Dalam perhitungan ini ada beberapa asumsi yang digunakan yaitu:

- Volume dan kualitas limbah sebelum dan setelah proyek sama $\left(225 \mathrm{~m}^{3} /\right.$ hari)
- Kedua fasilitas dianggap menjadi satu fasilitas dalam perhitungannya karena ketiadaan data mengenai debit untuk masing-masing unit IPAL.

\section{d. Pengurangan Beban COD}

Jumlah limbah yang dihasilkan adalah $225 \mathrm{~m}^{3} /$ hari, dengan konsentrasi COD 3.000 $\mathrm{kg} / \mathrm{m}^{3}$. Diasumsikan bahwa limbah sebelumnya tidak diolah, dan karena tidak ada data yang tersedia, maka efisiensi pengurangan COD nya diperkirakan hanya sekitar $10 \%$, sedangkan dalam proyek, diketahui bahwa laju penurunan COD dalam skenario proyek adalah $98 \%$ (dari $30.000 \mathrm{~g} / \mathrm{m}^{3}$ menjadi $68 \mathrm{~g} / \mathrm{m}^{3}$ ). Dari hasil asumsi tersebut diketahui bahwa pengurangan beban COD setelah adanya proyek adalah 214 tCOD/tahun (Tabel 9. Perhitungan penurunan COD di Lampiran)

\section{e. Pengurangan GRK}

Berdasarkan uraian di atas, diketahui bahwa sistem pengolahan limbah di Sentra Industri Tahu Adiwerna adalah kombinasi antara anaerobik digestion dengan pengolahan sistem aerobik pada lagoon (kolam) aerobik. Sedangkan sebelum proyek dilaksanakan, diasumsikan bahwa limbah dibuang ke lingkungan. Dalam kegiatan ini juga diasumsikan bahwa lumpur yang dihasilkan tidak diproses, sehingga tidak diperhitungkan dalam analisis ini. Dengan demikian maka, persamaan emisi GRK(5) adalah sebagai berikut:

$$
B E_{\mathrm{CO}_{2}, y}=\mathrm{BE}_{\mathrm{CO}_{2}, \mathrm{ww}, y}
$$

Dimana:

$$
\begin{aligned}
& B E_{\mathrm{CO}_{2} w w, y}=\sum_{i, m}\left(Q_{w w, m, y} * C O D_{\text {removed }, i, m, y}\right. \\
& \left.* M C F_{\text {anaerobic }, i}\right) B_{O} * U F_{B L} * G W P_{C_{4}}
\end{aligned}
$$

Dimana :

$B E \quad$ : skenario dasar emisi GRK (tCO2e)

$Q \quad$ : debit air limbah (m3/tahun)

Mcf : factor koreksi metana(Tabel 2-4 (1))

Ufel : faktor koreksi model(1.06)

GWPCH4: potensi metana global warming: 21

Bo : potensi generasi metana

Maksimum (IPCC default) (3)

$0,21\left(\mathrm{kgCH}_{4} / \mathrm{kg} \mathrm{COD}\right)$

Dari hasil perhitungan dapat dihitung bahwa pengurangan emisi GRK karena adanya proyek ini adalah sebesar $508 \mathrm{tCO}_{2} \mathrm{e} /$ tahun.

\section{f. Keuntungan Terhadap Masyarakat}

Berdasarkan pengelolaan air limbah di Sentra Industri Tahu Adiwerna maka didapat 
keuntungan ganda yaitu mengurangi pencemaran lingkungan dan keuntungan ekonomi. Keuntungan eknomi ini dapat dirasakan oleh masyarakat secara langsung yaitu melalui limbah pakan ternak dan hasil produksi gas metana dari instalasi pengolahan air limbah tahu. Limbah yang dihasilkan dari proses pembuatan tahu dapat digunakan sebagai alternatif pakan ternak. Hal tersebut dilakukan karena dalam ampas tahu terdapat kandungan gizi. Yaitu, protein $(23,55 \%)$, lemak $(5,54 \%)$, karbohidrat (26,92\%), abu (17,03\%), serat kasar (16,53\%), dan air (10,43\%).

Gas metana yang merupakan salah satu bentuk biogas bersifat tidak berbau, tidak berwarna dan sangat mudah terbakar. Pada umumnya di alam tidak berbentuk sebagai gas murni namun campuran gas lain yaitu metanaa sebesar $65 \%$, karbondioksida $30 \%$, hidrogen disulfida sebanyak $1 \%$ dan gas-gas lain dalam jumlah yang sangat kecil. Biogas sebanyak 1000 $\mathrm{ft} 3\left(28,32 \mathrm{~m}^{3}\right)$ mempunyai nilai pembakaran yang sama dengan 6,4 galon ( 1 US gallon $=3,785$ liter) butana atau 5,2 gallon gasolin (bensin) atau 4,6 gallon minyak diesel.

Untuk memasak pada rumah tangga dengan 4-5 anggota keluarga cukup $150 \mathrm{ft} 3$ per hari. Proses dekomposisi limbah cair menjadi biogas memerlukan waktu sekitar 8-10 hari. Satu kilogram tahu menghasilkan sekitar 29 gram $\mathrm{CH} 4$ jadi gas metana yang dapat dikeuntungankan masyarakat adalah $440 \mathrm{~kg}$ (setara dengan $11.000 \mathrm{~kg} \mathrm{CO} 2)$ per hari. Jumlah keluarga yang mekeuntungankan gas metana adalah 40 keluarga di IPAL sebelah selatan dan 60 keluarga di IPAL Utara.

Masyarakat di sekitar dapat menggunakan hasil gas metana melalui pipapipa yang disediakan oleh pengelola. Gas digunakan untuk keperluan masak sehari-hari sehingga masyarakat tidak perlu membeli gas dari Pertamina ataupun membeli minyak tanah, tetapi mereka hanya membayar iuran gas metana secara bulanan ke pengelola. Untuk pemasangan pipa gas masyarakat harus membayar biaya pemasangan sekitar Rp.150.000,- dengan cara cicilan yang dapat dibayar selama 3 bulan. Sedangkan untuk pembayaran bulanan dilakukan dengan sistem sebagai berikut:

- Masyarakat sekitar yang menghasilkan air limbah dari industri tahu dan mengalirkan air limbah tahu ke IPAL hanya membayar Rp. 10.000,- per bulan.

- Masyarakat sekitar yang tidak menghasilkan air limbah tahu hanya membayar Rp. 15.000 ,- per bulan.

\section{KESIMPULAN}

1) Perbaikan manajemen limbah dan pengelolaan limbah cair secara memberikan kontribusi terhadap penurunan jumlah limbah cair yang dihasilkan, serta penurunan jumlah energi yang digunakan.

2) Pembuatan fasilitas pengolahan limbah cair tahu dengan metode anaerobik yang dipadukan dengan sistem lagoon. Kegiatan ini, memiliki dampak positif terhadap:

- Penurunan konsentrasi COD di effluen

- Penangkapan gas metana untuk sumber bahan bakar/memasak 100 rumah tangga

- Penurunan indeks bau yang diakibatkan oleh terlepasnya volatile organik carbon dalam saluran limbah.

3) Analisis co-benefits pada kegiatan ini menggunakan Tier (Tingkat Kesulitan) 2 dan Tier (Tingkat Kesulitan) 3.

4) Katagori Pengelolaan Limbah menyebabkan penurunan jumlah emisi dengan dihasilkannya gas metana dan penurunan konsentrasi COD yang dihasilkan dari adanya proyek ini tidak dapat dikuantifikasi secara series, karena ketiadaan data dasar.

5) Katagori peningkatan kualitas dengan menetapkan asumsi debit air limbah 225 $\mathrm{m}^{3} /$ hari, dengan konsentrasi COD 3000 $\mathrm{kg} / \mathrm{m}^{3}$. Diasumsikan limbah sebelumnya tidak diolah karena tidak ada data, maka efisiensi pengurangan COD nya sekitar $10 \%$, sedangkan dalam proyek, diketahui penurunan $\mathrm{COD}$ dalam skenario proyek adalah $98 \%$ (dari $30000 \mathrm{~g} / \mathrm{m}^{3}$ menjadi 68 $\mathrm{g} / \mathrm{m}^{3}$ ). Sehingga pengurangan beban $\mathrm{COD}$ setelah adanya proyek adalah 214 tCOD/tahun (perhitungan penurunan COD di Lampiran).

6) Berdasarkan hasil perhitungan diketahui bahwa pengurangan emisi GRK karena adanya proyek ini adalah sebesar 508 $\mathrm{tCO}_{2} \mathrm{e} /$ tahun.

7) Keuntungan yang dapat dirasakan oleh masyarakat secara langsung yaitu melalui limbah pakan ternak dan hasil produksi gas metana dari IPAL tahu. 


\section{DAFTAR PUSTAKA}

1. Minister of Environment of Japan. Manual for Quantitative Evaluation of the Co-Benefits Approach to Climate Change Projects (Ver 1.0), Minister of Environment Japan, 2009.

2. Pacific Consultants, Report for Investigation of Support Strategy for Establishing CoBenefit Type Low Carbon Society in Indonesia, Pacific Consultants, Co., Ltd, 2010.

4. Hendrawati, T. et. Al, Pedoman Pengelolaan Limbah Kegiatan Peternakan dan Rumah Potong Hewan. Program agroindustry towards zero waste. Kementrian Lingkungan Hidup Republik Indonesia, 2009

5. Tsuji, K. Japan's Activities to Promote CoBenefit Approach. International Cooperation Office, Ministry of the Environment, Japan, 2009.

3. Eggleston, S., L. Buendia, K. Miwa, T. Nagara and K. Tanabe, IPCC Guidelines for National Greenhouse Gas Inventories. Institute for Global Environmental Strategies, Japan, 2006

6. Ishigaki Tomonori, Possibly Co-benefit? Advanced Wastewater Treatment Process, Department of Environmental Solution Technology Ryukoku University, Japan, 2009.

\section{LAMPIRAN}

Tanel 9. Perhitungan Penurunan Beban COD Setelah Implementasi Proyek di Sentra Industri Tahu Adiwerna, Kabupaten Tegal

\section{Persamaan A.1 Perhitungan Penurunan COD dari Air Limbah}

\begin{tabular}{|c|r|r|r|}
\hline Tipe Air Limbah & $\mathbf{B E}_{\mathrm{COD}}$ (Ton/tahun) & $\mathbf{P E}_{\mathrm{COD}}$ (Ton/tahun) & $\mathbf{E R}_{\mathrm{COD}}$ (Ton/tahun) \\
\hline & $\mathbf{( 1 )}$ & $\mathbf{( 2 )}$ & $\mathbf{( 3 ) = ( 1 ) - ( \mathbf { 2 } )}$ \\
\hline 1 & 221.7375 & 0.39125 & 214.34625 \\
2 & 0 & 0 & 0 \\
3 & 0 & 0 & 0 \\
4 & 0 & 0 & 0 \\
5 & 0 & 0 & 0 \\
dst & & & \\
\hline
\end{tabular}

Persamaan A.2 Perhitungan Beban COD di Discharge (Skenario Baseline)

\begin{tabular}{|c|c|c|c|c|c|c|}
\hline Tipe Air Limbah & $\mathrm{COD}_{\mathrm{f}}(\mathrm{mg} / \mathrm{L})$ & $\operatorname{COD}_{f}\left(T o n / m^{3}\right)$ & $Q\left(m^{3} /\right.$ hari $)$ & $\mathrm{Q}\left(\mathrm{m}^{3} /\right.$ Tahun $)$ & $\mathbf{R}_{\mathrm{COD}, \mathrm{BL}}$ & $\mathrm{BE}_{\mathrm{COD}}$ (Ton/Tahun) \\
\hline & (1) & (2) & (3) & (4) & (5) & (6) \\
\hline 1 & \multirow[t]{6}{*}{3000} & \multirow{6}{*}{\begin{tabular}{r|}
0.003 \\
0 \\
0 \\
0 \\
0
\end{tabular}} & \multirow[t]{6}{*}{225} & \multirow{6}{*}{$\begin{array}{r}82125 \\
0 \\
0 \\
0 \\
0\end{array}$} & \multirow[t]{6}{*}{0.1} & \multirow{6}{*}{$\begin{array}{r}221.7375 \\
0 \\
0 \\
0 \\
0\end{array}$} \\
\hline 2 & & & & & & \\
\hline 3 & & & & & & \\
\hline 4 & & & & & & \\
\hline 5 & & & & & & \\
\hline dst & & & & & & \\
\hline
\end{tabular}

Persamaan A.3 Perhitungan Beban COD di Discharge (Skenario Proyek)

\begin{tabular}{|c|c|c|c|c|c|c|}
\hline Tipe Air Limbah & $\mathrm{COD}_{\mathrm{f}}(\mathrm{mg} / \mathrm{L})$ & $\operatorname{COD}_{f}\left(T o n / m^{3}\right)$ & $\mathrm{Q}\left(\mathrm{m}^{3} /\right.$ hari $)$ & $Q_{p J}\left(m^{3} /\right.$ Tahun $)$ & $\mathbf{R}_{\text {COD,PJ }}$ & $\mathrm{PE}_{\mathrm{COD}}$ (Ton/Tahun) \\
\hline & $(1)$ & (2) & (3) & (4) & $(5)$ & $(6)$ \\
\hline 1 & 3000 & 0.003 & 225 & 82125 & 0.97 & 7.39125 \\
\hline 2 & & 0 & & 0 & & 0 \\
\hline 3 & & 0 & & & & 0 \\
\hline 4 & & 0 & & 0 & & 0 \\
\hline 5 & & 0 & & 0 & & 0 \\
\hline dst & & & & & & \\
\hline
\end{tabular}

